\title{
Procesos de alteración de las vidrieras medievales. Estudio y tratamientos de protección
}

\section{Alteration processes of medieval stained glass windows. Study and protection treatments}

Fecha de recepción: $20-$ III-96

J. Ma FERNÁNDEZ NAVARRO, Instituto de Cerámica y Vidrio, CSIC (Madrid)

Fecha de aceptación: 1-V-96

ESPAÑA

\section{RESUMEN}

La inquietud creada por la creciente alteración que, como consecuencia del aumento de la contaminación atmosfërica, están sufriendo las vidrieras históricas, ha movido a las instituciones de varios paises a patrocinar la realización de una serie de trabajos cientificos dirigidos, por una parte, a detener el avance de este deterioro $y$, por otra, a desarrollar. métodos para su restauración y conservación.

Tras una revisión inicial sobre la composicion quimica de las vidrieras y sus diferencias según las distintas épocas y' lugares de procedencia, se discuten los mecanismos de ataque quimico, los procesos de degradación v la formación de costras superficiales.

linalmente se expone brevemente la metodologia seguida para su limpieza y restauracion y se comentan algunos de los criterios sobre la todavia polémica cuestion de los tratamientos de protección.

\section{SUMMARY}

The anxiety caused by the fast growing decay of historical stained glass windows as a consequence of increasing environmental pollution, encouraged institutions of sereral countries to sponsor a series of scientific works aimed both to slow down this fast forwarding deterioration and to develop repair and preservation methods.

1fier an initial review of the chemical composition of the stained glass window's and of the differences depending on historical epochs and origins, a discussion about chemical attack mechanisms, degradation processes and formation of superficial crusts opens up.

Finally, the methodologe used in their cleaning and restoration is briefly exposed and some criteria on the still polemic question of treatments for protection are commented.

\section{INTRODUCCIÓN}

Los estudios sobre vidrieras medievales han experimentado un considerable incremento en los últimos 20 años. Al interés histórico-artístico que habia sido el móvil principal de investigaciones anteriores, ha venido a añadirse una razón decisiva de trascendental importancia: la de su restauración y protección ante el creciente deterioro que pone en peligro su supervivencia y amenaza con la pérdida de un patrimonio cultural de tamaña importancia. El ataque atmosférico natural que han venido sufriendo a lo largo de varios siglos de existencia, se ha intensificado a causa de la creciente contaminación atmosférica que ha agravado alarmantemente, sobre todo en las grandes ciudades y en las zonas industriales, las condiciones de agresión química (1).

El resultado de este ataque es una degradación del vidrio que lleva consigo el deterioro mecánico, la descomposición química, la alteración de los colores y la disminución de su transparencia originales.

\section{INTRODUCTION}

Studies about medieval stained glass windows have experimented a great increase in the last 20 lears. Idded to the historical-artistic interest of former investigations, now a more important reason appears: restoration and protection against the increasing decal. of the cultural heritage. It has undergone natural weathering through the centuries intensified by the increasing atmospherical pollution. This pollution has increased the glass corrosion. mainly in citics and industrial areas (I).

The result of this attack is glass degradation and. thus. its mechanical decay chemical damage. colours alteration and decrease of its original transparenci: 
La metodología a seguir para su estudio es similar en todos los casos y consta de las siguientes fases : caracterización y análisis del vidrio; identificación de las alteraciones; determinación de sus causas; decisión sobre los métodos de limpieza a emplear; restauración del vidrio y medidas de protección y conservación ulterior.

\section{COMPOSICIÓN QUÍMICA DE LOS VIDRIOS}

El conocimiento de la composición química de los vidrios que integran las vidrieras es especialmente importante por la variada información que puede proporcionar acerca de distintos aspectos de interés, tales como el tipo de vidrio, la época y el lugar de fabricación, el mecanismo y la gravedad del ataque químico sufrido, la naturaleza de los depósitos formados, el tratamiento de limpieza a emplear, el tratamiento de protección y la eventual reproducción de las piezas y su reposición. Con este fin algunos autores (2-6) han acumulado multitud de datos analíticos atendiendo especialmente a los componentes fundamentales de los vidrios.

\subsection{Contenido de sílice}

Debido al papel que desempeña la sílice como formador de red, su contenido determina en los vidrios de silicato su comportamiento físico-químico. Si la proporción de sílice desciende por debajo del $60 \%$ y no existen otros formadores de red, la estabilidad del vidrio disminuye considerablemente. El bajo contenido de sílice es una de las principales causas del deterioro de las vidrieras medievales, ya que en muchas de ellas éste se halla comprendido entre el 50 y el $60 \%$ y en algunas puede incluso descender hasta un $40 \%$.

Como tendencia general se observa que los vidrios del siglo XII tienen una proporción más elevada de sílice con valores próximos e incluso superiores al $60 \%$ en peso.

\subsection{Contenido de iones alcalinos}

Junto al contenido de sílice los factores que más influyen, sin duda, en la resistencia química de los vidrios son la naturaleza y la concentración de los óxidos alcalinos que intervienen en su composición. La elevada proporción de óxidos alcalinos que contienen los vidrios medievales, especialmente de óxido de potasio los hace muy vulnerables. Como es bien sabido, los vidrios sódico-cálcicos son mucho menos atacables que los potásico-cálcicos. De ambos óxidos alcalinos el más comúnmente empleado desde los orígenes de la
The methodology used is similar in all cases and is constituted by the following steps: glass characterization and analysis; identification of alteration; determination of causes; choice of the suitable methods for cleaning; glass restoration and later, protection and conservation.

\section{CHEMICAL COMPOSITION OF THE GLASSES}

The knowledge of the chemical composition of glasses is especially important because of the large information it provides about different aspects of interest, such as glass type, age and manufacturing place, chemical attack mechanisms and severiousness nature of deposits formed, cleaning method to utilize, protective treatment and if necessary, pieces reproduction and replacement. Some authors (2-6) have obtained numerous chemical analysis results regarding principally the fundamental components of the glasses.

\subsection{Silica content}

Because silica acts as network former, its content determines the physico-chemical behaviour of silicate glasses. If silica proportion is below $60 \%$ and there are not other network formers, glass stability decreases considerably. The silica low content is one of the main decay causes in medieval glasses, because most of them have silica contents between 50 and $60 \%$ and in some of cases, it can decrease even below $40 \%$.

As a general trend, it is observed that XIIth century glasses have higher silica contents with values close to $60 \%$ wt. or even higher.

\subsection{Alkali ions content}

Factors influencing chemical resistance of glasses (besides silica content) are the nature and concentration of alkali oxides. The high proportion of alkali oxides (especially potassium oxide) of medieval glasses, make them very vulnerable. As it is known, soda-lime glasses are less attackable than those potash-lime ones. Irom both alkaline oxides, soda was the most commonly employed since glasses manufacturing origin. Potash-lime glasses appeared during the high Middle Age in factories established in 
fabricación del vidrio fue el de sodio. Los vidrios potásico-cálcicos surgieron durante la alta Edad Media en los talleres establecidos en los bosques centroeuropeos, que por hallarse alejados de las rutas del comercio de las materias primas sódicas, tuvieron que recurrir como fuente de álcali al empleo de cenizas de la madera y de otras plantas, ricas en carbonato potásico. Las fórmulas químicas de estos vidrios potásicos se hallan contenidas en el viejo y famoso libro del monje Teófilo (7), que fue la obra clásica que sirvió de guía y recetario a muchos de los fabricantes de vidrieras medievales. La receta para preparar un vidrio establecía que debían mezclarse dos partes de cenizas de madera de haya con una parte de arena purificada.

De los vidrios que datan del siglo XII parte son sódicos y parte potásicos. Los potásicos tienen contenidos de óxido de potasio más bajos que los de épocas posteriores, generalmente inferiores al $15 \%$ en peso Sorprende encontrar vidrios de este siglo con porcentajes molares del 13 al $15 \%$ de $\mathrm{Na}_{2} \mathrm{O}$ procedentes de la catedral de York (3), junto a una mayoría de vidrios potásicos. Hay que señalar que curiosamente la mayoría de los vidrios de esa época con alto contenido de óxido de sodio son de color azul.

La época más crítica es la de los siglos XIII al XV en que predominan los vidrios potásicos, mucho más fácilmente alterables. No sólo aumenta el óxido de potasio hasta un $20-30 \%$ en peso, sino que al mismo tiempo la proporción de silice desciende hasta alrededor de un $50 \%$, variaciones ambas que contribuyen a disminuir la estabilidad química del vidrio. Por eso no debe llamar la atención que muchas vidrieras más antiguas estén mejor conservadas que otras fabricadas tres siglos después.

A partir del siglo XV se aprecia un cambio de composición con un aumento del porcentaje de sílice y una disminución del de óxido de potasio que redundan en un notable mejoramiento de la calidad del vidrio, si bien hasta el XVI no se reanudará la fabricación de vidrios sódicos, la cual ya se mantendrá en lo sucesivo de una forma regular.

\subsection{Contenido de óxido de calcio}

El porcentaje de óxido de calcio se mueve entre límites mucho más amplios, que pueden llegar hasta un 25-30\% en peso, aunque en la mayoría de los casos no suele sobrepasar el $20 \%$.

\subsection{Otros componentes}

Junto a estos tres componentes fundamentales hay que mencionar otros que, aunque en proporciones menores,
Central Europe forests. These lay far from commercial ways of soda and, thus, wood ashes were used as raw alkali likewise other plants rich in potassium carbonate. The composition of these potash glasses are summarized in the old and famous book of the monk Teofilo (7), the classical work that guided most glass manufacturers of the Middle Age. The recipe to prepare a glass says that two parts of beech wood ashes should be mixed with one part of purified sand to obtain it.

XIIth century glasses are partly soda and partly potash ones: Potash glasses have lower content of potassium oxide than those of later epochs, generally lower than 15 wt\%. It is surprising to find glasses from this century. like those from York ('athedral (3) with molar percentages of 13 to $15 \%: \mathrm{V} \mathrm{a}_{2} \mathrm{O}$. between a majority of potash glasses: It is worth mentioning that most glasses from this epoch with high sodium oxide content are blue.

The most critical epoch is that between. WIIth and 17 th centuries in which potash glasses are more common. these glasses are easier to altere. Iot only potassium oxide increases until 20-30\% wt., but, at the same time. silica proportion decreases until a $50 \%$. both variations contributing to decrease chemical stability. of the glass. By this reason. it is not surprising that many ancient glasses are better conserved than some manufactured three centuries later.

Since. Wl th century: a change in composition is observed, with an increase in silica percentage and a decrease in potassium oxide involving notable enhancement of glass quality. But until .1TTh century: soda glasses manufacturing is not resumed. This trend is then maintained regularly.

\subsection{Calcium oxide content}

('alcium oxide percentage is between wider limits. These limits can reach 25-30\% w.. although. in most cases. $20 \%$ is not reached.

\subsection{Other components}

Together with these three main components, there are other that, although in lower proportions. appear as a 
aparecen como una constante en casi todas las muestras de vidrieras. Los principales son los óxidos de magnesio, bario, plomo, aluminio, titanio y fósforo.

$\mathrm{El} \mathrm{MgO}$ interviene generalmente en porcentajes molares comprendidos entre un 6 y un $10 \%$. El óxido de magnesio era aportado por las cenizas de madera que lo contienen en una proporción aproximada de un $12 \%$.

$\mathrm{E} 1 \mathrm{PbO}$ ha sido encontrado en vidrios de color verde oscuro (8) (9) en proporciones de alrededor de un 5 a un $13 \%$, pero puede llegar hasta un 40 a $50 \%$. Naturalmente, los vidrios que lo contienen en estas concentraciones han llegado hasta nosotros en buen estado de conservación. El ataque atmosférico de estos vidrios da lugar a la formación de sulfuro de plomo, que es muy estable y crea sobre la superficie del vidrio una capa que lo protege de ataques ulteriores.

Los óxidos de aluminio y titanio, así como parte del de calcio, proceden de las arcillas empleadas para la fabricación de los crisoles, como consecuencia del progresivo ataque de éstos por el vidrio fundido y su incorporación a él.

El pentóxido de fósforo es un componente habitual de los vidrios medievales (10) (11); se halla presente en concentraciones muy variables que oscilan entre unas pocas centésimas \% y alrededor de un $5 \%$. Es muy improbable que fuera adicionado con una finalidad determinada, por lo que cabe pensar que se incorporara formando parte de las cenizas utilizadas como materia prima alcalina.

Müller (6) (9) establece cinco tipos de vidrios (Tabla I) atendiendo a los componentes principales $\mathrm{SiO}_{2}, \mathrm{CaO}$, $\mathrm{K}_{2} \mathrm{O}, \mathrm{Na}_{2} \mathrm{O}, \mathrm{PbO}$ y $\mathrm{P}_{2} \mathrm{O}_{5}$. constant in all glasses. These are magnesium, barium, lead, aluminum, titanium and phosphorus oxides.

$\mathrm{MgO}$ is generally present in molar percentages between 6 and 10\%. Magnesium oxide was introduced by wood ashes in which it is present in $12 \%$ approximately.

PbO has been found in glasses with dark green colour (8) (9) in proportion of about 5 to $13 \%$, but it can reach 40 to $50 \%$. Naturally, glasses containing these concentrations are now in good state of conservation. Weathering of these glasses leads to lead sulphide formation, a very stable compound that creates a film on glass surface, protecting it from later attacks.

Aluminum and titanium oxides, as well as a part of calcium oxide, proceed from clays used for crucibles manufacturing, as a consequence of their corrosion by glass melts.

The phosphorous pentoxide is a normal component of medieval glasses (10) (11); it is present in variable concentrations between little hundredth and $5 \%$. It is improbable that it was deliberately added and, thus, it is logical to think that it was introduced as a part of the ashes used like alkaline raw material.

Müller (6) (9) establishes five types of glasses depending on their main components SiO, ( $a \mathrm{OO}, \mathrm{K}, \mathrm{O}$. $\mathrm{Na}_{2} \mathrm{O}, \mathrm{PbO}$ and $\mathrm{P}_{2} \mathrm{O}_{5}$ (Table I).

TABLA I (TABLE /)

Tipos de composición de vidrieras medievales. (Según Müller, Torge y Adam) (6) Composition types of medieval stained glass windows. (After Müller Torge and Adam)(6)

\begin{tabular}{|c|c|c|c|c|c|c|c|}
\hline \multicolumn{8}{|c|}{ COMPOSICION (peso) \%) } \\
\hline $\begin{array}{c}\text { Tipo de vidrio } \\
\text { Glass type }\end{array}$ & $\mathrm{SiO}$ & $\mathrm{CaO}$ & $\mathrm{k}, \mathrm{O}$ & $\mathrm{Na}, \mathrm{O}$ & $\mathrm{PbO}$ & $\mathrm{P}, \mathrm{O}_{!}$ & $\begin{array}{l}\text { Color } \\
\text { Color }\end{array}$ \\
\hline 1 & $45-55$ & $15-25$ & $15 \cdot 2.5$ & 0.2 & $0-1$ & $0-4$ & $\begin{array}{l}\text { diverso } \\
\text { diverse }\end{array}$ \\
\hline 2 & $45 \cdot 55$ & $25 \cdot 35$ & $10 \cdot 15$ & 0.2 & 0.1 & 0.4 & $\begin{array}{l}\text { diverso } \\
\text { diverse }\end{array}$ \\
\hline 3 & $60-75$ & 1.6 & 58 & $10-18$ & 0.1 & 0.4 & $\begin{array}{l}\text { a cul } \\
\text { bluse }\end{array}$ \\
\hline 4 & 3040 & $5 \cdot 20$ & 5.20 & $0-1$ & $10-50$ & 0.10 & $\begin{array}{l}\text { verde } \\
\text { green }\end{array}$ \\
\hline$b$ & $55 \cdot 70$ & $10-20$ & $2-8$ & $2-8$ & $0-1$ & 3.10 & $\begin{array}{l}\text { diverso } \\
\text { diverse }\end{array}$ \\
\hline
\end{tabular}


Los vidrios del tipo 1 y del tipo 2 se diferencian en que en los primeros la relación $\mathrm{CaO} / \mathrm{K}_{2} \mathrm{O}$ es menor de $2 \mathrm{y}$ en los segundos, mayor de 2 . La inmensa mayoría de las vidrieras está constituida por vidrios del tipo 1; los del tipo 2 son muy escasos; los vidrios azules del tipo 3 sólo corresponden al siglo XII; los del tipo 4 se encuentran a lo largo de toda la época medieval, y los del tipo 5 pertenecen al periodo renacentista. LoS vidrios del tipo 3 son los que se hallan mejor conservados.

\subsection{Colorantes}

En el estudio de alteración de las vidrieras hay que considerar, además del deterioro químico del vidrio, las alteraciones que han sufrido los colores. Puede observarse de modo general una importante disminución de la transparencia, debida no sólo a la acumulación de depósitos de suciedad (polvo y hollín del humo de las velas en el interior) y a la formación de costras opacas de sales, sino también a los cambios del estado de oxidación de algunos iones inducidos fotoquímicamente por la irradiación luminosa a la que han estado secularmente expuestos. Por eso deben también considerarse los distintos elementos empleados como agentes colorantes ( $\mathrm{Co}, \mathrm{Mn}, \mathrm{Fe}, \mathrm{Cu}$ ).

\subsection{1. Óxido de cobalto}

El color azul intenso se obtenía siempre utilizando sales de cobalto. Su uso ha sido general en todas las vidrieras desde el siglo $\mathrm{X}$. Como han puesto de manifiesto los análisis realizados por Chesnau (12), Vassas (13) y Bettembourg (14) en vidrios azules de diversas catedrales francesas, por Kühne (15) en muestras de la catedral de Stendal y por Geilmann (16) en muestras de distintas procedencias, el óxido de cobalto, cuyo contenido varía generalmente entre un 0,1 y un $1 \%$, suele estar acompañado de contenidos de $\mathrm{CuO}$ variables entre un 0,05 y un $0,5 \%$. La aportación de este colorante se hacía mediante el empleo de diversos minerales de cobalto, tales como el sulfuro y el arseniuro.

\subsection{2. Óxido de manganeso}

Con la función de colorante y -más frecuentemente- de decolorante, hay que citar al óxido de manganeso.

Aunque se usó como colorante para producir la coloración rosa de las carnaciones y más tarde -a partir del siglo XVI- para obtener el color violeta, el hecho de que aparezca en concentraciones muy variables hace pensar que en muchos casos su incorporación fuera puramente accidental, como impureza de las cenizas alcalinas. En efecto, Geilmann y Brückbauer (17)
Glasses of type 1 and type 2 are differentiated in their $\mathrm{CaO} / \mathrm{K}_{2} \mathrm{O}$ ratio. This ratio is below 2 in type I glasses and above 2 in type II glasses. Most of the stained glass windows are constituted by type 1 glasses; type 2 glasses are very rare; blue glasses of type 3 correspond only to XIIth century; type 4 glasses are found along Middle Age and type 5 glasses are from the Renaissance. Type 3 glasses are those better conserved.

\subsection{Colouring oxides}

In the study of stained glass windows alteration, besides the chemical attack, alterations undergone by colours must be considered. Generally, an important decrease in transparency can be observed, not only due to dirt accumulation (dust, soot from candles) and to the formation of opaque salt layers, but also to the oxidation of some ions photochemically induced by light. By this reason, different elements used as pigments must be considered ( $\mathrm{Co}, \mathrm{Mn}, \mathrm{Fe}, \mathrm{Cu})$.

\subsubsection{Cobalt oxide}

The intense blue colour was always obtained using cobalt salts. Their utilization have been general in all stained glass windows from Xth century. As it has been shown by analyses carried out by Chesnau (12), Vassas (13) and Bettembourg (14) in blue glasses from various french cathedrals, by Kühne (15) in samples from Stendal cathedral and by Geilmann (16) in samples of different origins, cobalt oxide, whose content varies generally between 0,1 and $1 \%$, is accompanied by variable $\mathrm{CuO}$ contents between 0,05 and $0,5 \%$ This component was added through the use of several cobalt minerals, such as sulphides and arsenides.

\subsubsection{Manganese oxide}

Manganese oxide must be cited because it has been used as colouring and, more frequently as decolouring agent.

Although it was used to produce the pink colour of skin and, later-since XVIth century- to obtain purple colour, its appearing in variable concentrations indicates that it was introduced accidentally in most of the cases, as impurity of alkaline ashes. In fact, Geilmann and Brückbauer (17) determined manganese content in beech ashes from different places and, they 
determinaron el contenido de manganeso en las cenizas de madera de haya de distintos lugares y obtuvieron valores comprendidos entre un 0,1 y un $10 \%$.

Lo que se desconocía entonces es que el óxido de manganeso, que en su estado reducido $\mathrm{Mn}^{2+}$ no produce color, experimenta una fotooxidación por efecto de la acción prolongada de la luz solar y pasa al estado de oxidación $\mathrm{Mn}^{3+}$ que imparte un color violeta al vidrio de acuerdo con la reacción:

$$
\mathrm{Mn}^{2+}+\mathrm{hv}---->\mathrm{Mn}^{3+}+\mathrm{e}
$$

Este proceso de solarización da lugar a una disminución progresiva de la transmitancia del vidrio y a un cambio de la tonalidad de sus colores originales. La coloración violeta puede hacerse desaparecer de forma reversible calentando el vidrio por encima de unos $450{ }^{\circ} \mathrm{C}$, si bien este tratamiento, además de entrañar el riesgo de formación de fisuras, es a la larga de escasa utilidad a causa de la reversibilidad del proceso.

Por otra parte, el manganeso extraido del vidrio a lo largo del proceso de corrosión puede llegar a oxidarse hasta su estado tetravalente dando lugar a una oscura coloración parda. Estas sales de manganeso, que son poco solubles, quedan retenidas en la película de gel formada sobre la superficie del vidrio y también se acumulan en las zonas de vidrio más atacadas, donde llegan a alcanzar concentraciones superiores al $10 \%$ (18), produciendo un intenso oscurecimiento. Pueden eliminarse mediante un lavado ácido o por un tratamiento reductor con una solución de hidrazina.

\subsection{3. Óxido de hierro}

Lo mismo que el de manganeso, el óxido de hierro era una impureza habitual, no sólo de las cenizas potásicas, sino también de otras materias primas que, en conjunto, podian elevar el contenido de este óxido por encima de un $0,5 \%$ en peso. La presencia simultánea de ambos óxidos da lugar a una amplia gama de tonalidades como consecuencia de las reacciones redox que se establece entre ellos (19).

\subsection{4. Óxido de cobre}

Este es el colorante comúnmente empleado para impartir coloraciones azul y verde turquesa. Muchos vidrios con contenidos de óxido de cobre de alrededor del 1 al $2 \%$ presentan una buena estabilidad química, debido a que en su composición intervienen porcentajes relativamente elevados de $\mathrm{PbO}$ y/o de $\mathrm{P}_{2} \mathrm{O}_{5}$ (3) (8) y también de óxido de sodio (6). obtained values between 0,1 and $10 \%$.

But it was unknown that manganese oxide (that in its reduced state $\mathrm{Mn}^{2+}$ produces no colour) experiments photoxidation by sun light effect and transforms into $\mathrm{Mn}^{3+}$ that provides a purple colour according to the reaction:

$$
\mathrm{Mn}^{2+}+h v---\cdots \mathrm{Mn}^{3+}+\mathrm{e}
$$

This process leads to a progressive decrease of glass transmittance and to a change in colours. Purple colour disappears reversibly heating the glass above $450^{\circ} \mathrm{C}$, but this treatment can provoke cracks and it is not useful because its reversibility.

On the other hand, manganese ions extracted from glass along corrosion process may be oxidized to its tetravalent state giving place to a darkbrown colour. These manganese salts, little soluble, are retained in the gel film formed on glass surface and they are also accumulated in the glass most attacked zones, where they can reach concentrations higher than $10 \%$ (18), producing an intense darkness. They can be eliminated by acid washing or by a reducing treatment with hydrazine solution.

\subsubsection{Iron oxide}

The same as manganese oxide, iron oxide was a normal impurity, not only of the potash ashes, but also of other raw materials that could increase this oxide content to 0.5 $w t \%$. The simultaneous presence of both ions can give rise to a wide colour hues depending on the redox processes which take place among them (19).

\subsubsection{Copper oxide}

This is the colouring agent most commonly employed to impart blue and turquoise green colours Many glasses with copper oxide contents of about 1 to $2 \%$ present good chemical stability because in their composition, relatively high percentages of $\mathrm{PbO}$ and/or $\mathrm{P}_{2} \mathrm{O}_{5}(3)(8)$ and sodium oxide (6) are present. 
El color verde se obtenía por la presencia conjunta de óxido cúprico y óxido férrico en vidrios fundidos en condiciones oxidantes (13). Gran parte de estos vidrios verdes han llegado asimismo en un buen estado de conservación, debido igualmente a su elevado contenido de óxido de plomo (6) (9) (20).

El óxido de cobre desempeña un papel especialmente importante en la producción de los colores rojos rubí, que han sido estudiados por varios autores (21-24).

\subsection{Capas de grisalla}

Al estudiar analíticamente la superficie del vidrio hay que tener en cuenta la posible existencia de capas de grisalla que también son de naturaleza vítrea, aunque de muy distinta composición. Generalmente estaban constituidas por mezclas de sustancias fácilmente vitrificables, coloreadas por iones de transición, que, una vez fundidas, se molían, se suspendían en aceite, se aplicaban como pintura sobre el vidrio y se horneaban a temperaturas que debían de estar próximas a unos 500 a $600{ }^{\circ} \mathrm{C}$. Frecuentemente entraba en la composición de las grisallas óxido de plomo como fundente. La presencia de éste aumentaba su estabilidad química y por ello se hallan muchas veces en mejor estado de conservación que el vidrio sustrato. Sin embargo, pueden estar parcialmente desprendidas como consecuencia de una mala adherencia o por efecto de tensiones creadas por diferencias entre sus coeficientes de dilatación. En tal caso la superficie del vidrio subyacente suele estar mucho más atacada. Cuando las capas de grisalla también sufren los efectos de la corrosión, el daño suele ser irreparable, pues, debido a su delgado espesor, se atacan rápidamente y se mezclan de forma inseparable con los productos de ataque, haciendo imposible la recuperación del trazado original.

\subsection{Influencia de la composición química sobre la alterabilidad de las vidrieras}

El deterioro y la degradación que han sufrido las vidrieras a lo largo de los siglos tienen su origen fundamentalmente en dos tipos de causas: de naturaleza mecánica y de naturaleza química. Entre las primeras hay que citar principalmente las roturas causadas por impactos, por vibraciones, por golpes de viento, por tensiones mecánicas internas, por dilatación térmica, por deformación de la estructura metálica o por manipulaciones de reparación y de desmontaje.

En lo que a la degradación química se refiere, es la consecuencia de la meteorización progresiva que ha sufrido el vidrio en su cara externa durante el prolongado ataque atmosférico a que ha estado
Green colour was obtained by the joint presence of cupric oxide and ferric oxide in glasses melted in oxidizing conditions (13). Most part of these green glasses are in good state of conservation due to their high lead oxide content (6)(9)(20).

The copper oxide plays a especially important role on the ruby colour glasses, which has been studied by different authors (21-24).

\subsection{Grisaille layers}

In the analytical study of glass surface, the possible presence of grisaille layers must be taken into account. These are of vitreous nature, although with very different compositions. Generally, they were constituted by mixtures easily vitrifiable, coloured by transition ions. Once melted, they were grounded, suspended in oil and applied as a paint on glass. Then, they were heated at temperatures close to 500 to $600^{\circ} \mathrm{C}$. Frequently, lead oxide was a component of grisaille composition as a melting agent. The presence of this lead oxide increased its chemical stability and hence, they are sometimes better conserved than the substrate glass. However, they can be partially removed as a consequence of bad adherence or by strains created by differences in their expansion coefficients. In such case, glass surface is much more attacked. When grisaille layers underwent corrosion effects, damage may be irreversible because, due to their feeble thickness, they are rapidly corroded and mixed with the attack products; so it is impossible to recover the original traced.

\subsection{Influence of the chemical composition on the stained glass windows alteration}

The decay and degradation that stained glass windows have undergone along centuries have their origin mainly in two types of causes: mechanical nature and chemical nature causes. Among the first, rupture by means of impacts, vibrations, wind charges, internal mechanical strains, thermal expansion, metallic structure deformation or repairing or mounting manipulation must be cited.

With respect to chemical degradation, it is the consequence of the glass progressive attack of its external surface exposed to weathering along centuries. To these alterations the corrosive effects 
expuesto a lo largo de los siglos. A estas alteraciones hay que sumar los efectos corrosivos producidos por las deyecciones de las aves. En su cara interna, protegida de la intemperie, no es menos grave el efecto debido a la condensación de humedad, favorecido por las grandes concentraciones humanas y por las diferencias de temperatura entre el exterior y el interior. Como se verá más adelante, las minúsculas gotitas de agua formadas, que permanecen largo tiempo depositadas sobre el vidrio, ejercen una acción mucho más fuertemente corrosiva de lo que a primera vista pudiera pensarse y precisamente sobre la superficie pintada del vidrio, en la que los daños producidos son mucho más irreparables.

La atacabilidad química de los vidrios ha sido objeto de numerosos estudios (25) (26). Principalmente está influida, como es sabido, por la proporción relativa de óxidos formadores, estabilizantes y modificadores, y por la naturaleza más o menos básica de éstos.

En cuanto a los óxidos formadores que más comúnmente intervienen en los vidrios medievales $\left(\mathrm{SiO}_{2}, \mathrm{Al}_{2} \mathrm{O}_{3}, \mathrm{P}_{2} \mathrm{O}_{5}\right.$ ), se ha comprobado que sólo cuando la suma de sus porcentajes molares es superior al $60 \%$ se han mantenido inatacables al paso del tiempo. Por debajo de este valor aparecen con picaduras o con costras. La influencia de los óxidos alcalinos sobre la durabilidad del vidrio es tambièn decisiva, tanto por lo que se refiere al porcentaje molar en que intervienen como a su naturaleza. Sin embargo, ambos datos deben considerarse cuidadosamente atendiendo al resto de los componentes para evitar interpretaciones erróneas. El porcentaje máximo de óxidos alcalinos que limita la estabilidad química de los vidrios puede estimarse entre un 16 y un $20 \%$, dependiendo de la proporción de los otros óxidos. Respecto a la naturaleza de los óxidos alcalinos, puede afirmarse, en general, que los vidrios potásicos son mucho más atacables químicamente que los sódicos.

En tercer lugar figura el conjunto de los óxidos del tipo $\mathrm{RO}$, entre los que el de calcio es el que interviene en mayor proporción. Desde el punto de vista de la durabilidad química del vidrio, más importante que un elevado porcentaje de $\mathrm{CaO}$ es que la relación $\mathrm{CaO} / \mathrm{K}_{2} \mathrm{O}$ sea lo más alta posible. Dentro de los óxidos RO hay que incluir el $\mathrm{PbO}$ que, como ya se ha indicado, aumenta considerablemente la estabilidad química del vidrio.

El ataque químico de las vidrieras se inicia en ambiente húmedo y puede transcurrir de acuerdo con distintos mecanismos (27) (28). En un medio acuoso primeramente se adsorbe una delgada película de agua, cuyas moléculas se fijan mediante puentes de hidrógeno sobre los grupos silanoles $\mathrm{Si}-\mathrm{OH}$ existentes en la produced by birds excrements are joint. In its internal side, protected from weathering, it is not less important the effect of humidity condensation, favoured by large human concentrations and by temperature differences between internal and external environments. As it will be seen later, the small water drops placed on glass for a long time, provoke a very aggressive action, particularly on painted glass surface, in which damage is much more irreparable.

Chemical attack of glasses have been extensely studied (25)(26). It is mainly influenced, as it is known, by proportion of former, stabilizer and modifier oxides and it is also influenced by the more or less alkaline nature of these oxides

Regarding network former oxides most commonly present in medieval glasses $\left(\mathrm{SiO}_{2}, \mathrm{Al}_{2} \mathrm{O}_{3}, \mathrm{P}_{2} \mathrm{O}_{5}\right)$, it has been verified that only when the sum of their molar percentages is higher than $60 \%$, glasses remained unaltered through the time. Below this value, they appear with pittings or crusts. The influence of alkali oxides on glass durability is also decisive, regarding to their nature and their molar percentage. However, both data must be considered taking care of the other components to avoid erroneous interpretations. Maximum percentage of alkali oxides that limits chemical stability of glasses can be estimated between 16 and $20 \%$, depending on other oxides proportion. With respect to the nature of alkali oxides, it can be affirmed, in general, that potash glasses are much more chemically attackable than soda glasses.

On third place, the set of RO type oxides must be mentioned, among which calcium oxide is the one present in higher proportion. From the view point of glass chemical durability, a $\mathrm{CaO} / \mathrm{K}_{2} \mathrm{O}$ ratio as high as possible is more important than a high $\mathrm{CaO}$ percentage. Among RO oxides, $\mathrm{PbO}$ must be included, that, as it has been cited, considerably increases glass durability.

Chemical attack of stained glass windows begins in humid environment and can occur according to different mechanisms (27)(28). In an aqueous medium, a water thin film is first adsorbed, whose molecules are fixed through hydrogen bonds on silanol groups $\mathrm{Si}-\mathrm{OH}$ in glass surface. Water molecules penetrate 
superficie del vidrio. Las moléculas de agua penetran de forma progresiva, difundiéndose hacia el interior $y$ formando una capa de gel de sílice, la cual,

inicialmente, puede incluso actuar como una barrera protectora. Paralelamente a esta difusión, tiene lugar un ataque del vidrio a cargo de los protones o de los hidroxilos del agua. Dependiendo de cuál de estas dos especies iónicas predomine, se establecerán condiciones ácidas o básicas. En un medio acuoso neutro el vidrio no debería sufrir ninguna alteración aparte de su hidratación superficial. Así es, ciertamente, cuando el vidrio se encuentra sumergido en agua en exceso o cuando el agua en contacto con él se renueva de forma continua, como sucede en el caso de la lluvia o de un lavado con agua corriente. En tales casos el ataque hidrolítico no tiene mayores consecuencias. Por el contrario, en contacto con una pequeña cantidad de agua y en condiciones estáticas, en las que ésta no se renueve ni se evapore fácilmente por hallarse en una atmósfera saturada de humedad, se produce un intenso ataque. Así, paradójicamente, la acción prolongada de pequeñas gotas de agua depositadas sobre el vidrio o bien una película de humedad condensada sobre su superficie producen un efecto mucho más corrosivo que un gran volumen de agua. El ataque en condiciones de neutralidad se inicia, igual que el ataque en medio ácido, por intercambio iónico de los protones del agua con los iones alcalinos del vidrio:

$$
\begin{gathered}
\mathrm{H}_{2} \mathrm{O}-->\mathrm{H}^{+}+\mathrm{OH}^{-} \\
-\mathrm{Si}-\mathrm{O}-\mathrm{R}^{+}+\mathrm{H}^{+}+\mathrm{OH}^{-}-->-\mathrm{Si}-\mathrm{OH}+\mathrm{R}^{+}+\mathrm{OH}^{-}
\end{gathered}
$$

La entrada de protones en el vidrio determina la salida de iones alcalinos y un aumento creciente de la concentración de grupos $\mathrm{OH}^{-}$en el medio acuoso. $\mathrm{Si}$ éste no se renueva, sino que permanece estacionario en contacto con el vidrio y se encuentra en pequeña cantidad, se va haciendo cada vez más básico y, por lo tanto más agresivo, produciendo la destrucción progresiva de la red vítrea.

$$
-\mathrm{Si}-\mathrm{O}-\mathrm{Si}-+\mathrm{R}^{+}+\mathrm{OH}^{-}-\cdots>\mathrm{O}-\mathrm{Si}-\mathrm{OH}+\mathrm{O}-\mathrm{Si}-\mathrm{O}-\mathrm{Na}^{+}
$$

De esta manera se producen manchas localizadas formadas por depósitos salinos que a veces son indelebles o muestran una lesión profunda. Esta es la explicación de por qué con frecuencia la cara interior de las vidrieras aparece fuertemente atacada. El agua condensada sobre la superficie del vidrio como consecuencia de la saturación de humedad en el ambiente por efecto de la concentración de grandes masas humanas, es la responsable de esa corrosión interior.

El ataque húmedo se acentúa por la presencia de otros agentes químicos de la atmósfera o contaminantes de ella, como son el $\mathrm{CO}_{2}$, el $\mathrm{SO}_{2}$, el $\mathrm{SO}_{3}$ resultante de la progressively, diffusing to the inner part and forming a silica gel layer which initially can act as a protective barrier. Parallel to this diffusion, glass attack takes place by means of protons or water hydroxils. Depending on which of these two ionic species dominate, acid or basic conditions are established. In an aqueous neutral medium, glass would not undergo any alteration apart from its surface hydration. So it is when glass is immersed in excess of water or when water in contact with it is continuously renovated, as in the case of rain or of abundant running water. In such cases, hydrolytic attack has no damage consequences. Oppositely, in contact with a small water amount and under static conditions in which water is not renovated and evaporated because humidity saturated environment, an intense attack is produced. So, long term action of small water drops deposit on glass or a water condensed film on its surface, produce a much more corrosive effect than large water amounts. The attack in neutral conditions begins, the same as acid medium attack, by ionic exchange of water protons with glass alkali ions:

$$
\begin{gathered}
\mathrm{H}_{2} \mathrm{O}--\cdots \mathrm{H}^{+}+\mathrm{OH}^{-} \\
-\mathrm{Si}-\mathrm{O}-\mathrm{R}^{+}+\mathrm{H}^{+}+\mathrm{OH}^{-}-\cdots
\end{gathered}
$$

Protons entrance in glass determines alkali ions exit and an increase of $\mathrm{OH}^{-}$groups concentration in the aqueous medium. If this is not renovated, remains steadily in contact with the glass in small amount, it becomes more alkaline with time and thus, more aggressive, producing progressive destruction of the vitreous network:

$$
-\mathrm{Si}-\mathrm{O}-\mathrm{Si}-+\mathrm{R}^{+}+\mathrm{OH}^{-}-\mathrm{O}-\mathrm{Si}-\mathrm{OH}+\mathrm{O}-\mathrm{Si}-\mathrm{O}-\mathrm{Na}^{+}
$$

In this way, local flecks are produced. These stains are formed by salt deposits that sometimes are indelibles or show a deep damage. This is the explanation to the attack of the glass in the inner side. Condensed water on glass surface as a consequence of humidity saturation in the environment or by effect of human masses concentration is the responsible for this internal corrosion.

Humid attack is enhanced by the presence of other chemical agents from the atmosphere or pollutants as $\mathrm{CO}_{2}, \mathrm{SO}_{2}, \mathrm{SO}_{3}$ resulting from the former 
oxidación del anterior y algunos óxidos de nitrógeno $\mathrm{NO}_{\mathrm{x}}$, que reaccionan con los iones alcalinos o alcalinotérreos extraídos, formando depósitos insolubles, de naturaleza cristalina, principalmente carbonatos y sulfatos. Los nitratos son muy solubles y no dan lugar a depósitos.

La corrosión comienza en los puntos más solubles de la superficie del vidrio. Primeramente se produce una extracción de los iones alcalinos por efecto del agua atmosférica acidulada por el $\mathrm{CO}_{2}$ y el $\mathrm{SO}_{2}$, que dan lugar a la formación de compuestos solubles. Una vez eliminados los iones alcalinos, permanecen los óxidos formadores junto con el óxido de calcio. Según hemos comprobado en vidrios sódico-cálcicos comunes sometidos a una prolongada corrosión por pequeñas gotas de agua en un ambiente saturado de humedad, los iones sodio se difunden hacia la periferia de la gota (29) (Fig. 1), mientras que la sílice y el óxido de calcio oxidation, and some nitrogen oxides that react with the alkaline or alkaline-earth ions extracted, forming insoluble deposits of crystalline nature, mainly carbonates and sulphates. Nitrates are very soluble and do not form deposits.

Corrosion begins in more soluble points of glass surface. First, takes place the leaching of alkali ions by effect of atmosferic water, acidulated by $\mathrm{CO}_{2}$ and $\mathrm{SO}_{2}$ giving place to soluble compounds. Once alkali ions are eliminated, former oxides observed remain joint to calcium oxide. As in common soda-lime glasses subjected to prolonged corrosion by small water drops in humidity saturated environment, sodium ions are diffused to drop boundaries (29) (Fig. 1), whereas silica and calcium oxide remain
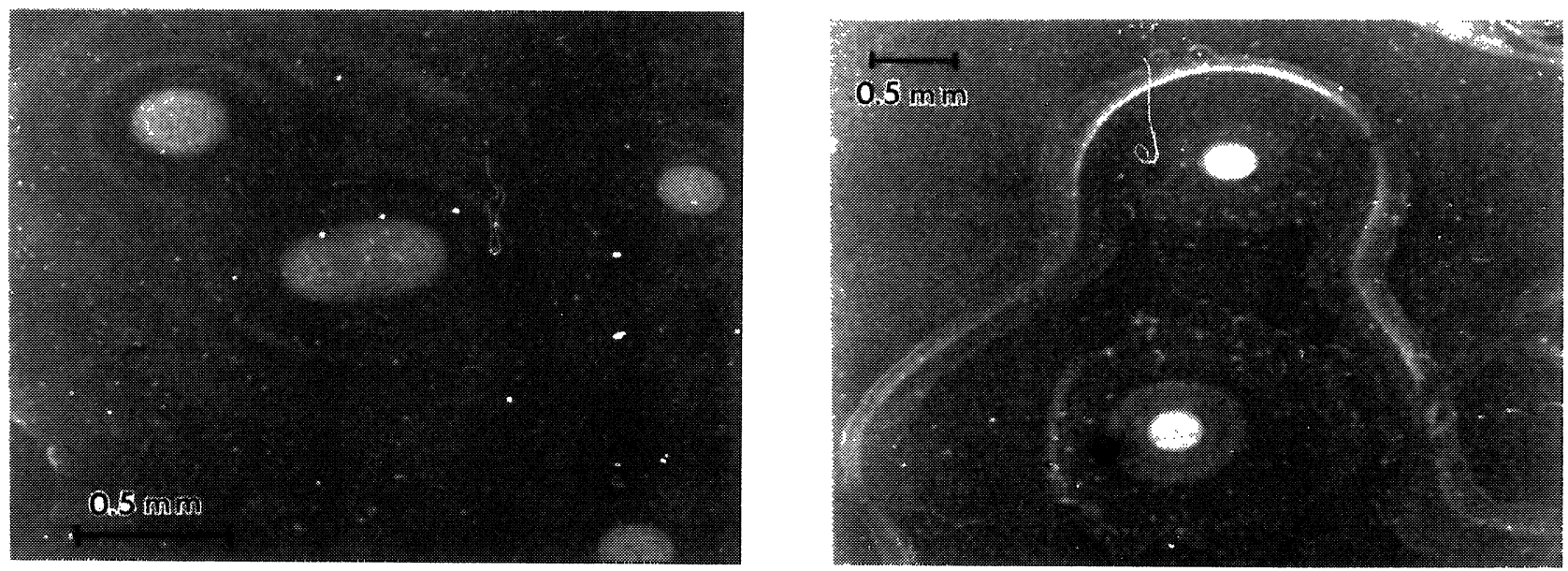

Fig. 1.- Huella dejada por gotas de agua de condensación sobre la superficie de un vidrio sílico-sódico-cálcico. Fig. 1.- Fine attack produced by water droplets condensation on the surface of a common soda-lime glass.
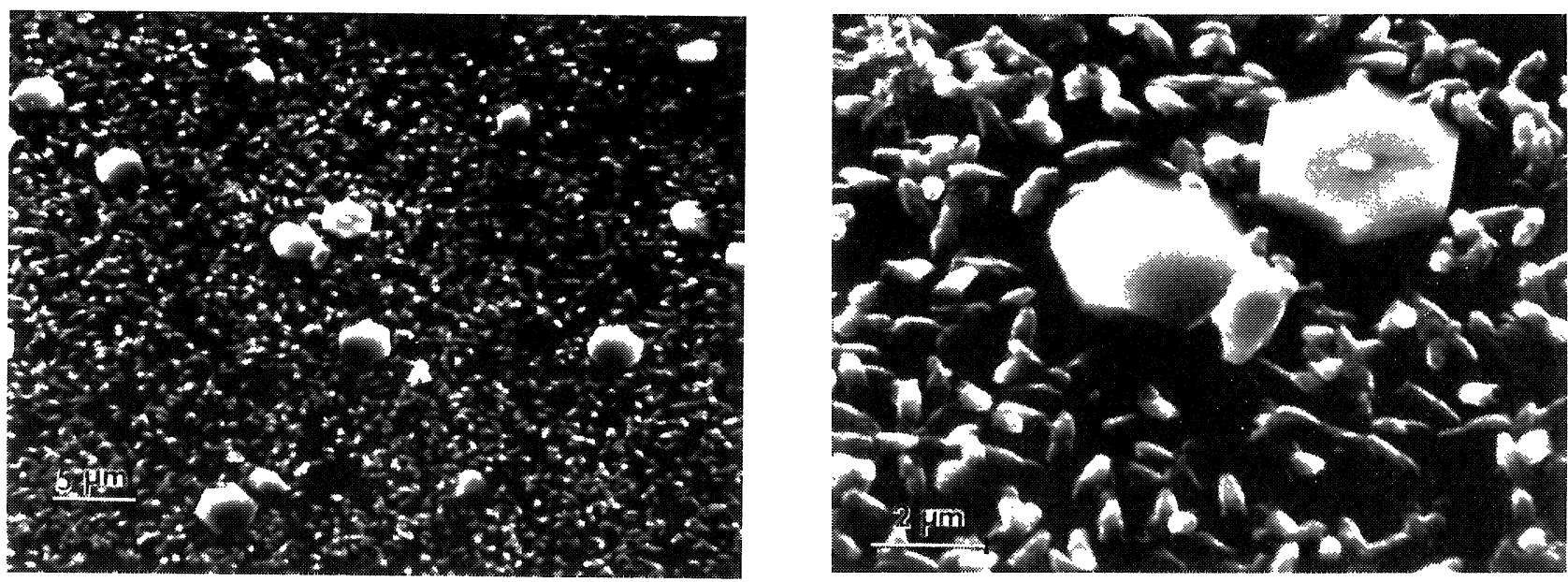

Fig. 2.- Cristales de carbonato cálcico formados por el ataque prolongado de las gotas de agua de la figura anterior sobre el mismo vidrio. Fig. 2.- Calcium carbonate crystals formed by a prolonged corrosion of the fine water droplets showed in former figure. 
permanecen en la zona central formando un núcleo insoluble de carbonato cálcico (Fig. 2), cuya morfología es muy semejante a la observada por Nauer y Kny (30).

Pérez y Jorba y col. (31) consideran que primeramente se forma hidróxido cálcico que después pasa a carbonato y por último a sulfato hidratado:

$$
\mathrm{Ca}(\mathrm{OH})_{2}-\cdots>\mathrm{CaCO}_{3}-\cdots>\mathrm{CaSO}_{4} \cdot 2 \mathrm{H}_{2} \mathrm{O}
$$

La formación de sulfatos alcalinos también puede ser el resultado directo de una extracción previa de los iones alcalinos en un medio húmedo combinada con la acción del dióxido de azufre, según la reacción propuesta por Douglas e Isard (32):

$$
\begin{aligned}
& -\mathrm{Si}-\mathrm{O}-\mathrm{R}^{+} \\
& -\mathrm{Si}-\mathrm{O}-\mathrm{R}^{+}
\end{aligned}
$$

Se trata de un proceso de intercambio de los iones alcalinos $\mathrm{R}^{+}$del vidrio por iones $\mathrm{H}^{+}$del medio, controlado por la velocidad de difusión de éstos a través de la superficie del vidrio. En los vidrios que contienen pentóxido de fósforo, éste en presencia de carbonato cálcico puede también contribuir a la formación de hidroxiapatito, en virtud de las siguientes reacciones (11):

$$
\begin{aligned}
& 6 \mathrm{CaHPO}_{4} \cdot 2 \mathrm{H}_{2} \mathrm{O}+3 \mathrm{CaCO}_{3}-\cdots>\mathrm{Ca}_{9}\left(\mathrm{PO}_{4}\right)_{6} \cdot 1 / 2 \mathrm{H}_{2} \mathrm{O} \\
& +3 \mathrm{CO}_{2}+11,5 \mathrm{H}_{2} \mathrm{O}
\end{aligned}
$$

A temperaturas por encima de $40{ }^{\circ} \mathrm{C}$ la reacción transcurre según:

$$
\begin{aligned}
& 12 \mathrm{CaHPO}_{4} \cdot 2 \mathrm{H}_{2} \mathrm{O}-\cdots-\mathrm{Ca}_{9}\left(\mathrm{PO}_{4}\right)_{6} \cdot 1 / 2 \mathrm{H}_{2} \mathrm{O}+ \\
& 3 \mathrm{Ca}\left(\mathrm{H}_{2} \mathrm{PO}_{4}\right)_{2}+23,5 \mathrm{H}_{2} \mathrm{O} \\
& \mathrm{Ca}_{9}\left(\mathrm{PO}_{4}\right)_{6} \cdot 1 / 2 \mathrm{H}_{2} \mathrm{O}+\mathrm{Ca}(\mathrm{OH})_{2}-\cdots>\mathrm{Ca}_{10}\left(\mathrm{PO}_{4}\right)_{6}(\mathrm{OH})_{2} \\
& +1 / 2 \mathrm{H}_{2} \mathrm{O}
\end{aligned}
$$

\subsubsection{Formación de depósitos o costras superficiales}

Como consecuencia de la extracción iónica que tiene lugar en los puntos de mayor solubilidad, se inicia una corrosión química que se manifiesta en forma de picaduras aisladas, más o menos profundas, o como una alteración uniforme de toda la superficie. Cuanto mayor es la proporción de potasio, mayor es el número de puntos de ataque que aparecen y más profundos son los cráteres formados. A medida que progresa el ataque químico, los productos de reacción depositados sobre la superficie del vidrio forman capas cuyo espesor puede llegar a ser de algunos milímetros, constituídas mayoritariamente por sílice amorfa y por sulfatos. Entre estas capas y el vidrio base se forma una película in the centre, forming an insoluble nucleus of calcium carbonate whose morphology is similar to that observed by Nauer and Kny (30) (Fig. 2).

Pérez y Jorba et al. (31) consider that calcium hydroxide is first formed, after it transforms to carbonate and, later, to hydrated sulphate:

$\mathrm{Ca}(\mathrm{OH})_{2}-\mathrm{-a} \mathrm{CaCO}_{3}-\mathrm{C} \mathrm{CaSO}_{4} \cdot 2 \mathrm{H}_{2} \mathrm{O}$

Alkaline sulphates formation may be also the direct result of a previous extraction of alkaline ions in humid medium, combined with the action of sulphur dioxide, according to the reaction proposed by Douglas and Isard (32):

$$
\begin{aligned}
& -\mathrm{Si}-\mathrm{O} \cdot \mathrm{R}^{+} \quad-\mathrm{Si}-\mathrm{OH} \\
& +\mathrm{H}_{2} \mathrm{O}+\mathrm{SO}_{2}+1 / 2 \mathrm{O}_{2}-\cdots+\mathrm{R}_{2} \mathrm{SO}_{4} \\
& -\mathrm{Si}-\mathrm{O} \cdot \mathrm{R}^{+} \quad-\mathrm{Si}-\mathrm{OH}
\end{aligned}
$$

This is a ion exchange process between $R^{+}$alkali ions from glass and $H^{+}$ions from the medium, controlled by diffusion rate of the latter through glass surface. In glasses containing phosphorus pentoxide, hydroxilapatite can be formed in calcium carbonate presence, according to the following reactions (II):

$$
\begin{aligned}
& 6 \mathrm{CaHPO}_{4} 2 \mathrm{H}_{2} \mathrm{O}+3 \mathrm{CaCO}_{3}---\mathrm{Ca}_{9}\left(\mathrm{PO}_{4}\right)_{6} \cdot 1 / 2 \mathrm{H}_{2} \mathrm{O} \\
& +3 \mathrm{CO}_{2}+11,5 \mathrm{H}_{2} \mathrm{O}
\end{aligned}
$$

At temperatures higher than $40^{\circ} \mathrm{C}$, reaction occurs according to:

$$
\begin{aligned}
& 12 \mathrm{CaHPO}_{4} 2 \mathrm{H}_{2} \mathrm{O}-\mathrm{Ca}\left(\mathrm{Ca}_{9}\left(\mathrm{PO}_{4}\right)_{6} \cdot 1 / 2 \mathrm{H}_{2} \mathrm{O}+\right. \\
& 3 \mathrm{Ca}\left(\mathrm{H}_{2} \mathrm{PO}_{4}\right)_{2}+23,5 \mathrm{H}_{2} \mathrm{O} \\
& \mathrm{Ca}_{9}\left(\mathrm{PO}_{4}\right)_{6} \cdot 1 / 2 \mathrm{H}_{2} \mathrm{O}+\mathrm{Ca}(\mathrm{OH})_{2}-\mathrm{Ca}_{10}(\mathrm{PO})_{6}(\mathrm{OH})_{2} \\
& +1 / 2 \mathrm{H}_{2} \mathrm{O}
\end{aligned}
$$

\subsubsection{Deposits and surface crusts formation}

As a consequence of leaching which takes place in highly soluble points, a chemical corrosion starts giving rise to isolated pittings, more or less deep, or to a regular alteration of all surface. The higher the potash content, the higher the number of attack points and the dipper the craters. As chemical attack progresses, reaction products deposited on glass surface form layers (whose thickness can reach some milimeters), constituted mainly by amorphous silica and sulphates. Among these layers and the glass substract, a gel film is formed as a result of alkali ions exchange by hydrogen ions. In this gel film, colouring oxides of low solubility can be accumulated. The 
de gel como resultado del intercambio de iones alcalinos del vidrio por iones hidrógeno. En esta película de gel pueden acumularse elementos colorantes poco solubles. La acumulación de los iones colorantes unida a la naturaleza policristalina de las capas de alteración, determinan una fuerte absorción luminosa que se traduce en un oscurecimiento del vidrio.

\subsubsection{Composición de las capas o costras de alteración}

Los análisis químicos de estos depósitos (33-40) muestran que están constituidos mayoritariamente por sílice, en proporciones que pueden variar entre el 30 y el $50 \%$; por $\mathrm{SO}_{3}$, con contenidos variables de un 17 a un $28 \%$; $\mathrm{CaO}$, de un 9 a un $15 \%$, y alrededor de un $10 \%$ de $\mathrm{K}_{2} \mathrm{O}$. Además de éstos, se pueden encontrar en proporciones minoritarias los restantes componentes del vidrio. Llama especialmente la atención el elevado porcentaje de agua que contienen, que entre la que se halla adsorbida y la que está estructuralmente unida al vidrio, puede alcanzar proporciones del 12 al $20 \%$.

Estos componentes se encuentran en general formando diversas fases cristalinas. Las más frecuentemente encontradas son:

-Sílice hidratada, $\mathrm{SiO}_{2} \cdot \mathrm{xH}_{2} \mathrm{O}$

-Sulfato cálcico dihidratado (yeso), $\mathrm{CaSO}_{4} \cdot 2 \mathrm{H}_{2} \mathrm{O}$

-Sulfato cálcico semihidratado (bassanita), $\mathrm{CaSO}_{4} \cdot 1 / 2 \mathrm{H}_{2} \mathrm{O}$

-Sulfato doble de potasio y calcio (singenita),

$\mathrm{K}_{2} \mathrm{Ca}\left(\mathrm{SO}_{4}\right)_{2} \cdot \mathrm{H}_{2} \mathrm{O}$

-Sulfato doble de potasio y calcio (gorgeyita),

$\mathrm{K}_{2} \mathrm{SO}_{4} \cdot 5 \mathrm{CaSO}_{4} \cdot \mathrm{H}_{2} \mathrm{O}$

-Sulfato de potasio, magnesio y calcio (polihalita),

$\mathrm{K}_{2} \mathrm{SO}_{4} \cdot 2 \mathrm{CaSO}_{4} \cdot \mathrm{MgSO}_{4} \cdot 2 \mathrm{H}_{2} \mathrm{O}$

-Sulfato doble de potasio y plomo (palmierita),

$\mathrm{K}_{2} \mathrm{~Pb}\left(\mathrm{SO}_{4}\right)_{2}$

-Sulfato magnésico (epsomita), $\mathrm{MgSO}_{4} \cdot 7 \mathrm{H}_{2} \mathrm{O}$

-Sulfato de bario (barita), $\mathrm{BaSO}_{4}$

-Sulfato de plomo (anglesita), $\mathrm{PbSO}_{4}$

-Sulfato de plomo, potasio y sodio (palmierita),

$(\mathrm{Na}, \mathrm{K})_{2} \mathrm{SO}_{4} \cdot \mathrm{PbSO}_{4}$

-Sulfato de hierro y potasio (jarosita), $\mathrm{K}_{2}(\mathrm{Fe} \cdot 2 \mathrm{OH})_{6}\left(\mathrm{SO}_{4}\right)_{4}$

-Carbonato cálcico (calcita), $\mathrm{CaCO}_{3}$

-Fosfato ácido de calcio, $\mathrm{CaHPO}_{4} \cdot 2 \mathrm{H}_{2} \mathrm{O}$

-Hidroxifosfato de calcio (hidroxiapatito),

$\mathrm{Ca}_{10}\left(\mathrm{PO}_{4}\right)_{6}(\mathrm{OH})_{2}$

-Oxalato cálcico, $\mathrm{Ca}(\mathrm{COO})_{2} \cdot 2 \mathrm{H}_{2} \mathrm{O}$

La sílice hidratada es una fase amorfa que aparece en todos los vidrios como consecuencia del ataque hidrolítico, originando una capa superficial de espesor variable. La formación de este gel está tanto más favorecida cuanto mayor sea la acidez del medio. accumulation of these joint to the polycrystalline nature of alteration layers, determines a strong light absorption that is responsable for a glass darkening.

\subsubsection{Composition of alteration layers or crusts}

Chemical analyses of these deposits (33-40) show that they are mainly constituted by silica, in proportions varying between 30 and $50 \%$; by $\mathrm{SO}_{3}$, with variable contents of 17 to $28 \%$; $\mathrm{CaO}$, of 9 to $15 \%$ and $10 \% \mathrm{~K}_{2} \mathrm{O}$ approximately. The rest of glass components can be also found in lower proportions. It is surprising the high water percentage (reaching 12 to 20\%) summing adsorbed water and that structurally bounded to glass.

These components are generally found forming several crystalline phases. The phases more frequently found are the following:

- Hydrated silica $\mathrm{SiO}_{2} \cdot \mathrm{xH}_{2} \mathrm{O}$

- Hydrated calcium sulphate (gypsum) $\mathrm{CaSO}_{4} \cdot 2 \mathrm{H}_{2} \mathrm{O}$

- Hemihydrated calcium sulphate (bassanite) $\mathrm{CaSO}_{4} \cdot 1 / 2 \mathrm{H}_{2} \mathrm{O}$

- Potassium and calcium double sulphate (singenite)

$\mathrm{K}_{2} \mathrm{Ca}\left(\mathrm{SO}_{4}\right)_{2} \cdot \mathrm{H}_{2} \mathrm{O}$

- Potassium and calcium double sulphate (gorgeyite) $\mathrm{K}_{2} \mathrm{SO}_{4} \cdot 5 \mathrm{CaSO}_{4} \mathrm{H}_{2} \mathrm{O}$

- Potassium, calcium and magnesium sulphate (polihalite)

$\mathrm{K}_{2} \mathrm{SO}_{4} \cdot 2 \mathrm{CaSO}_{4} \cdot \mathrm{MgSO}_{4} \cdot 2 \mathrm{H}_{2} \mathrm{O}$

- Lead and potassium double sulphate (palmierite)

$\mathrm{K}_{2} \mathrm{~Pb}\left(\mathrm{SO}_{4}\right)_{2}$

- Magnesium sulphate (epsomite) $\mathrm{MgSO}_{4} \cdot 7 \mathrm{H}_{2} \mathrm{O}$

- Barium sulphate (barite), $\mathrm{BaSO}_{4}$

- Lead sulphate (anglesite) $\mathrm{PbSO}_{4}$

- Lead, potassium and sodium sulphate (palmierite)

$(\mathrm{Na}, \mathrm{K})_{2} \mathrm{SO}_{4} \cdot \mathrm{PbSO}_{4}$

- Iron and potassium sulphate (jarosite) $\mathrm{K}_{2}(\mathrm{Fe} \cdot 2 \mathrm{OH})_{6}\left(\mathrm{SO}_{4}\right)_{4}$

- Calcium carbonate (calcite) $\mathrm{CaCO}_{3}$

- Acid calcium phosphate $\mathrm{CaHPO}_{4} \cdot 2 \mathrm{H}_{2} \mathrm{O}$

- Calcium hydroxiphosphate (hydroxiapatite)

$\mathrm{Ca}_{10}\left(\mathrm{PO}_{4}\right)_{6}(\mathrm{OH})_{2}$

- Calcium oxalate $\mathrm{Ca}(\mathrm{COO})_{2} \cdot 2 \mathrm{H}_{2} \mathrm{O}$

Hydrated silica is an amorphous gel phase which appears in all glasses as a consequence of hydrolytic attack, originating a surface layer of variable thickness. This gel formation is more favoured as acidity increases. 
La mayoría de las fases cristalinas depositadas son sulfatos. Dependiendo del porcentaje de óxidos alcalinos que contenga el vidrio, puede formarse sólo sulfato cálcico o sulfatos dobles.

\subsubsection{Representación de los vidrios según su resistencia química}

Para poder predecir el comportamiento químico de vidrios de diferente composición se han propuesto distintos sistemas de representación. Bettembourg (42) adopta un criterio basado en la representación de la relación entre los porcentajes atómicos " $\mathrm{Si}^{\prime \prime} / \mathrm{R}_{2}$ " (siendo "Si" la suma de los porcentajes atómicos de los iones formadores y " $R_{2}$ " la de los iones alcalinos) en función del porcentaje atómico de " $\mathrm{R}_{2}$ ". Este autor clasifica los vidrios según la Tabla II.
Most part of crystalline phases deposited are sulphates. Depending on glass alkali oxides percentage, calcium sulphate or double sulphates may be formed.

\subsubsection{Glasses representation according to their chemical resistance}

To predict chemical behaviour of glasses of different composition, different representation systems have been used. Bettembourg (42) proposes a criterion based on the representation of atomic percentage ratio "Si"/" $R_{2}$ "(being "Si" the sum of atomic percentages of network former ions and " $R_{2}$ " the one of alkali ions) as a function of " $R_{2}$ " atomic percentage. This author classifies glasses according to the following Table II.

TABLA II (TABLE II)

Clasificación de vidrios medievales atendiendo a su durabilidad química

(Según Bettembourg) (42)

Classification of medieval glasses according to their chemical durability. After Bettembourg (42)

\begin{tabular}{||l|c|c|}
\hline & $\mathrm{Si}_{2}$ & $\mathrm{R}_{2}$ \\
\hline $\begin{array}{l}\text { Estables } \\
\text { Stables }\end{array}$ & $>3$ & $<20 \%$ \\
\hline $\begin{array}{l}\text { Alterados por picaduras } \\
\text { Altered by pittings }\end{array}$ & 2,5 a 3 & 20 a $23 \%$ \\
\hline $\begin{array}{l}\text { Alterados uniformemente } \\
\text { Homogeneously altered }\end{array}$ & $<2$ & $>24 \%$ \\
\hline
\end{tabular}

Así obtiene para los vidrios potásicos la representación de la Fig. 3.
So, he obtained the representation of Fig. 3 for potash glasses

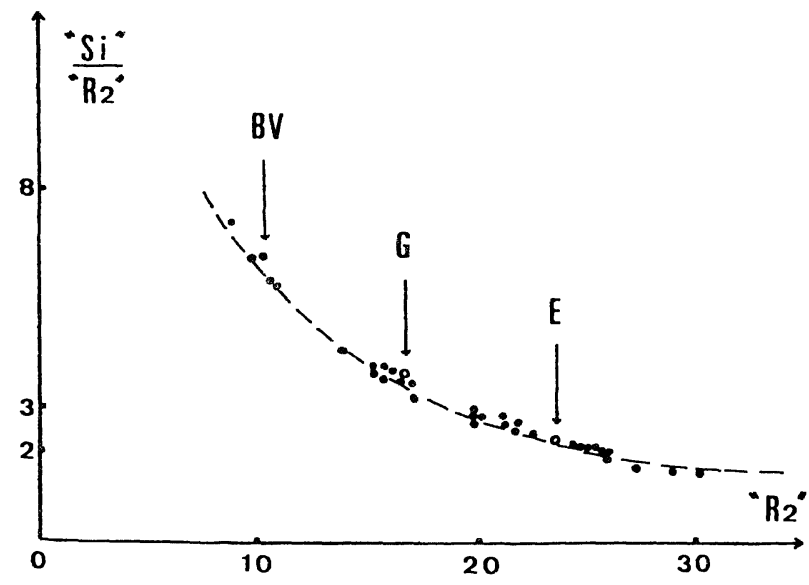

Fig. 3.- Representación grálica de la relación " $\mathrm{Si} / \mathrm{R}_{2}$ " en función de " $\mathrm{R}_{2}$ ". Según Bettembourg (42).

Fig. 3.- Representation of "Si/R $R_{2}$ ratio as a function of " $R_{2}$ ". After Bettembourg (42). 
Los vidrios de mayor durabilidad son los que quedan situados en la parte más alta a la izquierda de la curva y los más atacables, a la derecha y en la parte más baja.

La representación más común es la que se basa en un diagrama triangular, en cuyos vértices se agrupa la suma de cada uno de los tres tipos de componentes expresados en porcentajes molares, como han propuesto Iliffe y Newton (41). Los vidrios más atacables son aquéllos cuyas composiciones se hallan más alejadas del vértice $\mathrm{SiO}_{2}$ y más próximas al vértice $\mathrm{R}_{2} \mathrm{O}$ (Fig. 4).
Glasses of higher durability are those placed in the left up side of curve and those more attackable at right and down side.

The most common representation is based in a ternary diagram, in whose vertices is grouped the sum of each of the three most important components types expressed as molar percentages, as it has been proposed by Ilife and Newton (41). The most attackable glasses are those whose compositions are farest from $\mathrm{SiO}_{2}$ vertex and closest to $\mathrm{R}_{2} \mathrm{O}$ vertex (Fig. 4).

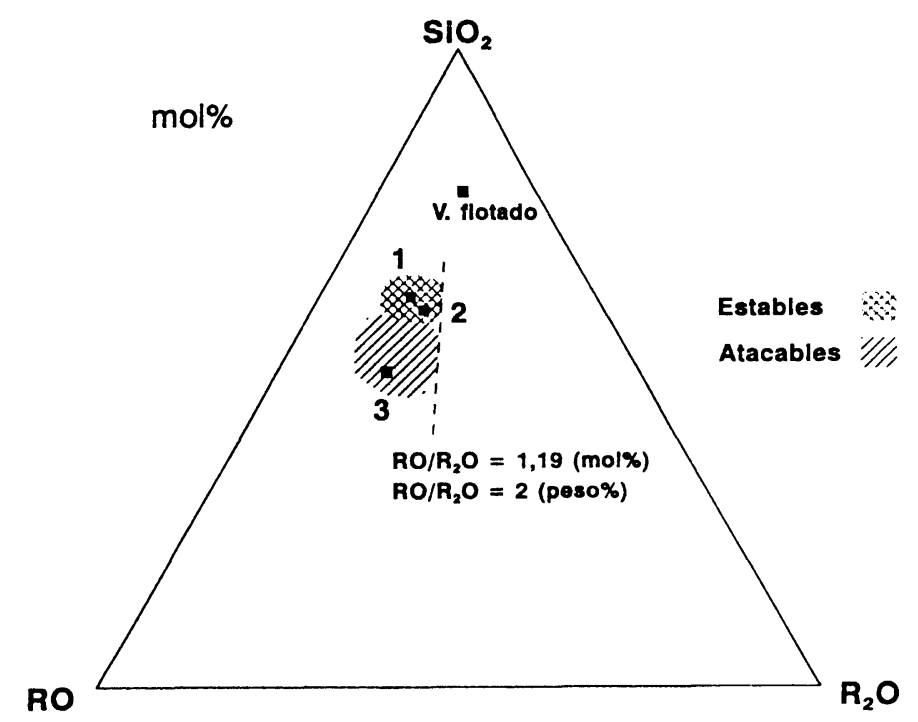

Fig. 4.- Diagrama ternario de composiciones en el sistema general $\mathrm{R}_{2} \mathrm{O}-\mathrm{RO}-\mathrm{SiO}_{2}$. La línea vertical de trazos representa la relación molar $\mathrm{RO} / \mathrm{R}_{2} \mathrm{O}=1,19$ (equivalente a la relación 2 en peso \%). Los puntos marcados con los números 1,2 y 3 corresponden a los valores de las relaciones "Si"/" $R_{2}$ " iguales a 3; 2,5 y 2 indicadas por Bettembourg (42).

Fig. 4.- Ternary compositions representation of the system $\mathrm{R}_{2} \mathrm{O}-\mathrm{RO}-\mathrm{SiO}_{2}$. Dashed vertical line means molar ratio $\mathrm{RO} / \mathrm{R}_{2} \mathrm{O}=1.19$ (equivalent to $2 \%$ wt. ratio). Points marked with 1,2 and 3 correspond to the values of "Si"/" $R_{2}$ " ratio equal to 3; 2.5 and 2 indicated by Bettembourg (42).

Si bien las predicciones de ambos sistemas de representación son correctas (pues cuanto menor sea la proporción de $\mathrm{SiO}_{2}$ y mayor la de $\mathrm{R}_{2} \mathrm{O}$, más atacable es el vidrio), resultan incompletas y sólo tienen un valor orientativo, pues ninguna de las dos establece diferencias cualitativas entre el tipo de iones alcalinos (sodio o potasio), -ya que ambos están englobados en un mismo término- $y$, por otra parte, la de Bettembourg (42) no tiene en cuenta el porcentaje de iones estabilizantes RO, los cuales juegan un papel tan importante en la estabilidad química del vidrio, como su nombre indica.

Cox y col. (3) y Gillies y Cox (26) representan el porcentaje molar total de óxidos $\mathrm{RO}$ en función del porcentaje de óxidos $\mathrm{R}_{2} \mathrm{O}$.
Predictions of both systems are correct (as $\mathrm{SiO}_{2}$ proportion is smaller and $\mathrm{R}_{2} \mathrm{O}$ proportion is larger, glass is more attackable), but they result incomplete and only give an orientative value because no qualitative differences between alkali ions type (sodium and potassium) are established, -because both ions are grouped in the same term-and, on the other hand, that of Bettemboug (42) do not take into account stabilizing ions percentage $R O$, that play an important role in glass chemical stability.

Cox et al. (3) and Gillies and Cox (26) represent total molar percentage of $\mathrm{RO}$ oxides as a function of $\mathrm{R}_{2} \mathrm{O}$ oxides percentage. 
Posteriormente Newton y Paul (43) han tomado como criterio para predecir la estabilidad química de los vidrios el valor de su energía libre de hidratación calculada a partir de los porcentajes molares de sus óxidos componentes, y han demostrado que existe una buena concordancia entre estos valores y el logaritmo de la cantidad de álcali extraído. Este criterio fue aplicado posteriormente con éxito por Newton y Fuchs (35) para establecer una concordante correlación entre el grado de ataque de vidrios de la catedral de York procedentes de distintas épocas y su composición. Los vidrios más atacados eran los correspondientes al siglo XII, que presentaban un valor considerablemente más negativo de su energía libre de hidratación que los que databan del siglo XV, que se hallaban mucho mejor conservados.

\subsubsection{Ataque por microorganismos}

Aunque menos frecuente que la corrosión atmosférica, hay que considerar también la producida por la acción de microorganismos. Las condiciones de temperatura, humedad y orientación geográfica de algunas vidrieras favorecen el asentamiento de hongos y líquenes sobre un medio como el vidrio, muchos de cuyos componentes pueden ser aprovechados como nutrientes. Los microorganismos desarrollan su actividad biológica a expensas de determinados iones que van extrayendo selectivamente del vidrio. Ello conduce a un empobrecimiento gradual de éste en iones potasio, magnesio y calcio y a su consiguiente degradación progresiva. También otros elementos, como el azufre, el hierro y el manganeso, habitualmente presentes en los vidrios medievales, son afectados por bacterias específicas cuyas necesidades de energía son satisfechas por la que se libera en las reacciones de oxidaciónreducción de estos elementos.

\section{TÉCNICAS PARA EL ESTUDIO DE LAS VIDRIERAS Y DE SUS ALTERACIONES}

El estudio químico de las vidrieras y de sus alteraciones requiere generalmente el concurso de varias técnicas de caracterización. En primer lugar debe inspeccionarse su estado de conservación, observando con un microscopio de luz ordinaria y de barrido los posibles defectos superficiales existentes (grietas, picaduras, manchas) y los depósitos formados. Esta observación preliminar debe ir seguida de un análisis químico tanto de la masa del vidrio como de su superficie, con el fin de poder establecer las diferencias de composición entre ambas y el grado de alteración sufrido. Una buena información complementaria sobre la profundidad del ataque y la extracción selectiva de los distintos componentes la proporciona un perfil de concentración obtenido por
Later, Newton and Paul (43) have set a criterion to predict glasses chemical stability based in hydration free energy calculated from molar percentages of their component oxides. They have demonstrated that a good concordance exists between these values and the logarithm of the extracted alkali amount. This criterion was later applied by Newton and Fuchs (35). They established a good concordance between attack degree of York cathedral glasses from different epochs and their composition. The most attacked glasses were that corresponding to XIIth century, which presented more negative values of their hydration free energy that those from XVth century, better conserved.

\subsubsection{Attack by microorganisms}

Although less frequently than weathering corrosion, the action produced by microorganisms action must also be considered. Conditions of temperature, humidity and geographical orientation of some stained glass windows favour the growing of fungi or lichens on glass that can be profitable as a nutrient. Microorganisms develop their biological activity from determined ions that they extract selectively from glass. This leads to a gradual loss of potassium, magnesium and calcium ions and to the glass subsequent degradation. Also other elements, as sulphur, iron and manganese, normally present in medieval glasses, are affected by specific bacteria whose energy requirements are satisfied by the energy released in oxidation-reduction reactions of these elements.

\section{TECHNICS FOR THE STUDY OF STAINED GLASS WINDOWS AND THEIR ALTERATIONS}

Chemical study of stained glass windows and their alterations requires generally the use of various characterization methods. First, conservation state must be investigated, observing with an ordinary light microscope and with a scanning microscope, possible surface defects (cracks, pittings, stains and deposits). This preliminary observation must be followed by a chemical analysis of the glass mass and its surface in order to establish composition differences between them and the alteration degree underwent. A good complementary information about attack depth and the selective extraction of the different components, gives a concentration profile obtained by dispersive energy $X$-ray spectrometry or by secondary ions mass 
espectrometría de rayos $\mathrm{X}$ por dispersión de energías o por espectrometría de masas de iones secundarios (SIMS) (44). Es obvio señalar que, siempre que sea posible, deben emplearse métodos analíticos no destructivos.

\section{REPARACIÓN Y CONSERVACIÓN DE LAS VIDRIERAS}

El aspecto más delicado y también la cuestión más polémica es la restauración. A ello se une la urgencia de tomar decisiones para evitar el deterioro creciente antes de que los daños sean irreversibles.

\subsection{Limpieza}

La primera operación que se requiere es la de limpieza que tiene por objeto eliminar las costras formadas por alteración química, los depósitos de suciedad y devolver los colores y la transparencia originales. Para ello se requiere la combinación de procedimientos mecánicos y químicos.

La limpieza mecánica se acostumbra a iniciar en seco mediante soplado con una boquilla de aire comprimido, seguido de un lavado con agua en un baño de ultrasonidos que se completa con un cepillado con cerdas suaves o un pulido con discos de fieltro que no lesionen el vidrio. También pueden emplearse minúsculas muelas abrasivas para eliminar restos fuertemente adheridos.

En cuanto a los métodos químicos de limpieza existen diferentes opiniones acerca de la conveniencia de su utilización. Para disolver las costras calcáreas se han ensayado con buen resultado agentes complejantes del calcio, como el EDTA o fosfatos, así como tiosulfato sódico, bicarbonato amónico y ácidos diluidos (45). El uso de ácido fluorhídrico diluido o de mezclas de ácido fluorhídrico y sulfúrico resulta muy eficaz para despegar los depósitos, pero es muy peligroso porque puede producir un ataque con formación de grietas.

La formación de depósitos de apatito, muy insoluble, puede explicar las dificultades encontradas en las operaciones de limpieza para solubilizar ciertos depósitos.

Cuando se limpien los vidrios, sobre todo los muy alcalinos, hay que tener en cuenta que, como consecuencia del prolongado ataque a que han estado sometidos, se hallan fuertemente desalcalinizados, y que al eliminar la costra de sulfato que les protegía resultan mucho más fácilmente atacables. Ello hace necesaria la aplicación superficial de un tratamiento spectrometry (SIMS)(44). Non destructive analytical methods must be employed when possible.

\section{STAINED GLASS WINDOWS REPAIR AND CONSERVATION}

The most difficult aspect and also the most polemic question is glass windows repair. The difficulty is joint to the necessity of taking a fast decision to avoid the decay before damages are irreversible.

\subsection{Cleaning}

Cleaning is the first step required to eliminate dirt deposits, crusts formed by chemical alteration and to recover colours and original transparency. For this purpose, combination of mechanical and chemical procedures is required.

Mechanical cleaning is carried out dry through blowing with compressed air, followed by cleaning with water in an ultrasonic bath, completed by brushing with soft bristles or polishing with felt discs not damaging glass. Also, very small abrasive discs can be used to eliminate strong fixed residues.

With respect to chemical methods of cleaning, different opinions exist about their utilization. To dissolve calcareous crusts, calcium complexing agents have been tested, as EDTA or phosphates, sodium thiosulphate, ammonium bicarbonate and diluted acids (45). The utilization of diluted hydrofluoric acid or hydrofluoric and sulphuric acid mixtures is also very effective to remove deposits, but it is dangerous because it can produce cracks.

The formation of very insoluble apatite deposits can explain difficulties for dissolving them.

When glasses are cleaned, mainly the most alkaline ones, as a consequence of the long-term attack to which they have been subjected, they are strongly disalkalized and when eliminating sulphate crust, they result easily attackable. This makes necessary the surface application of a protective treatment. When cleaning glass, the destruction or alteration of gel 
protector. Al realizar la limpieza del vidrio hay que evitar que se destruya o altere la película protectora de gel.

Como un caso particular de limpieza pueden considerarse los tratamientos químicos a que se somete el vidrio para recuperar su color original oscurecido por procesos fotoquímicos. Este el caso de los vidrios que contienen manganeso y en los que, como consecuencia de su progresiva degradación y de la extracción de otros componentes más solubles, este elemento ha ido acumulandose preferentemente en la película de gel que recubre el vidrio, así como en las grietas y otros puntos de ataque, y oxidandose al estado de $\mathrm{Mn}^{4+}$ responsable de la oscura coloración parda. Mediante el tratamiento con una solución acuosa de hidróxido de hidrazina al $25 \%$, empleado por Müller y col. (18), es posible decolorar el vidrio por reducción de los iones $\mathrm{Mn}^{3+} \mathrm{y}$ $\mathrm{Mn}^{4+}$ a $\mathrm{Mn}^{2+}$, en virtud de la reacción:

$\mathrm{N}_{2} \mathrm{H}_{4}+4 \mathrm{OH}^{-}+4 \mathrm{Mn}^{3+}---->4 \mathrm{H}_{2} \mathrm{O}+4 \mathrm{Mn}^{2+}+\mathrm{N}_{2}$

Los iones férricos no se reducen en estas condiciones.

En todos los tratamientos debe evitarse el calentamiento de los vidrios, ya que, debido a la intensa hidratación y desalcalinización que han sufrido, pueden producirse fisuras y grietas graves.

\subsection{Restauración}

La restauración tiene por objeto reparar los daños producidos. Ello exige, en unos casos, reparar los fragmentos rotos y en otros, volver a pintar los trazos perdidos. En el primer supuesto la reposición puede hacerse, en el mejor caso, utilizando vidrio original del que a veces se conservan fragmentos en reserva. De lo contrario es preciso fabricar piezas de vidrio cuyo espesor, textura superficial y, sobre todo, tono de color igualen lo más posible con los del original. En cuanto al repintado del vidrio original debe hacerse empleando preferentemente resinas, pues es desaconsejable la aplicación de colores vitrificables, debido al grave riesgo que siempre comporta el calentamiento de los vidrios antiguos.

\subsection{Protección}

Se han propuesto -y a veces se han empleado lamentablemente antes de que estuvieran suficientemente experimentados- muy variados tratamientos de protección. Así, a veces, se han aplicado sobre las vidrieras polímeros orgánicos y lacas para proteger la grisalla, que en unos casos han envejecido y en otros, han dado lugar a la acumulación protective film must be avoided.

As a particular cleaning case, chemical treatments for recovering the original colour of glass may be considered. This is the case of glasses containing manganese in which, as a consequence of its progressive degradation and the extraction of more soluble components, this element is accumulated mainly in gel film covering glass likewise in the cracks and other attack points. The oxidation to $\mathrm{Mn}^{4+}$ is responsible for the brown colour.

Through the treatment with an aqueous solution of hydrazine hydroxide at $25 \%$, used by Müller et. al. (18), it is possible to discolourize the glass reduzing the $\mathrm{Mn}^{3+}$ and $\mathrm{Mn}^{4+}$ ions to $\mathrm{Mn}^{2+}$ according to the reaction:

$\mathrm{N}_{2} \mathrm{H}_{4}+4 \mathrm{OH}^{-}+4 \mathrm{Mn}^{3+}-\cdots 4 \mathrm{H}_{2} \mathrm{O}+4 \mathrm{Mn}^{2}: \mathrm{N}_{2}$

Iron ions are not reduced in these conditions.

In all treatments, the heating of glasses must be avoided, because due to their intense hydration and disalkalization, strong crackings can be produced.

\subsection{Restoring}

Restoring is done in order to repair the damages produced. This requires, in some cases, to repair broken fragments and in other, to repaint the lost designs. In the first case, repair can be done using the original glass from which sometimes, fragments are available. If not, it is precise to manufacture glass pieces whose thicknes, surface texture and colour must be equal to the original one. The repaintig of the original glass, shall be carried out using resins, in order to avoid the risk of the heat treatments if vitrifiable colours were employed,

\subsection{Protection}

Different protection treatments have been proposed and, unfortunately, sometimes, they have been used without enough experimentation. So, sometimes; organic polymers and laques have been applied on the glass to protect grisaille that, in some cases has become older and, in others, it has led to dust accumulation with the formation of opaque black 
de polvo, formándose depósitos negros opacos. Para que los tratamientos sean aplicables deben satisfacer una serie de requisitos (46):

Desde el punto de vista técnico deben:

-Asegurar la fijación de la grisalla que se halle despegada -Proporcionar a la grisalla y, por lo tanto, a la pintura una protección duradera frente al agua de condensación -Aumentar apreciablemente la resistencia mecánica frente a la presión del viento

-Permitir conservar y aprovechar todos los fragmentos rotos sin necesidad de intercalar más perfiles de plomo -Permitir recuperar sin alteración el estado original de la vidriera

-Mantener el trazado original del emplomado sin ninguna nueva adición.

Desde el punto de vista físico-químico deben ser:

-Estables a la luz y a las temperaturas a que vayan a quedar expuestos

-Impermeables al agua y a los gases

-Inalterables por el agua

-Resistentes a la oxidación y a los agentes contaminantes - Adherentes al vidrio

-Compatibles con el vidrio

Desde el punto de vista artístico se requiere:

- Conservar la pátina

-Mantener los colores originales y la misma transparencia que antes del tratamiento - Adaptar las láminas de vidrio protectoras sin que se altere la superficie restaurada

-Disminuir la reflexión a un mínimo aceptable.

Además de estas condiciones se requiere que los recubrimientos protectores puedan ser eliminados de forma reversible sin dejar huella ni dañar el vidrio sobre el que fueron aplicados.

Para proteger la grisalla y la pintura se ha sugerido la aplicación de una fina capa vitrificable a baja temperatura, con una composición rica en óxido de plomo. El principal inconveniente de este tratamiento es el del riesgo de que durante el calentamiento del vidrio se formen fisuras o se propaguen las que ya puedan existir (46).

Otra alternativa es la de rellenar con un polímero orgánico los poros del vidrio atacado y forzar su penetración bajo vacío.

Más recientemente se ha recomendado la aplicación de deposits. Treatments must keep some conditions (46) to be suitable.

From the technical point of view they must:

- Ensure the fixing of removed grisaille

- Provide a durable protection for grisaille and paint against condensed water

- Increase significantly mechanical strength against wind pressure

- Permit conservation of all broken fragments without the intercalation of lead profiles

- Permit recovering the original state of the glass windows without alteration

- Maintain the original trace of lead holding without new additions

From the physical point of view, they must be:

- Stables to light and temperature

- Impermeable to water and gases

- Inalterable by water

- Oxidation and pollutant agents resistant

- Adherent to glass

- Compatible with glass

From the aesthetical point of view the following points are required:

- To conserve patina

- To maintain original colours and the same

transparency than before treatment

- To adapt protective glass layers without alteration of restored surface

- To decrease reflectivity to an acceptable minimum

Besides these conditions, it is required that protective coatings can be eliminated in a reversible way without glass damage.

To protect grisaille and paint, the application of a thin vitrifiable layer at low melting temperature has been suggested. The main disadvantage of this treatment is the risk of cracks appearing and the propagation of those existing when glass is heated (46).

Other alternative is the filling of glass pores with an organic polymer under vacuum in order to force its penetration.

More recently, the application of $\mathrm{SiO}_{2}$ or $\mathrm{SiO}_{2}$ and $\mathrm{TiO}_{2}$ 
recubrimientos de $\mathrm{SiO}_{2}$ o mixtos de $\mathrm{SiO}_{2}$ y $\mathrm{TiO}_{2}$ aplicados por el procedimiento sol-gel y tratados a $250^{\circ} \mathrm{C}(45)$. También se ha propuesto intercalar amplias zonas de la vidriera entre dos láminas nuevas de vidrio. Esto tiene, sin embargo, el inconveniente de que así no se remedian las grietas de la vidriera ni los defectos de la grisalla. Por otra parte, existe el riesgo de que entre las hojas de vidrio penetre el agua de condensación y produzca la consiguiente corrosión. Además, las zonas así protegidas resultan visibles desde el exterior por su diferente reflexión.

Asimismo se ha considerado la posibilidad de pegar el vidrio original a la lámina protectora mediante un intercalario de plástico como el que se emplea en los vidrios laminares de seguridad. Sin embargo, las irregularidades superficiales y la falta de planitud absoluta de la vidriera impiden una buena unión. Para salvar este inconveniente se ha pensado en aplicar primero para nivelar la superficie una masa polimérica de relleno que, después de colocar la nueva lámina de vidrio plano, se somete a un calentamiento a $80^{\circ} \mathrm{C}$ para llevar a cabo su polimerización. La protección de la vidriera mediante la superposición de una lámina de vidrio supone un importante aumento del peso con el consiguiente riesgo para su estabilidad.

Uno de los procedimientos más prometedores que se han ensayado ha sido el recubrimiento con silicatos modificados orgánicamente (47). Con tal fin se han empleado mezclas de tetraetoxisilano, difenildiclorosilano y metilvinildiclorosilano. Las principales ventajas de este tipo de materiales mixtos son que los alcoxisilanos que intervienen proporcionan un elevado número de grupos $\mathrm{Si}-\mathrm{OH}$ que aseguran la buena adherencia al vidrio y que poseen grupos hidrófobos. Por otra parte, se pueden eliminar sin riesgo para el vidrio ya que son fácilmente solubles en compuestos orgánicos. thin coatings by sol-gel procedure and treated at $250^{\circ} \mathrm{C}$ (45) has been recommended. Also, it has been proposed the intercalation of large glass windows areas between two new glass sheets. This has, however, the disadvantage of maintaining cracks and grisaille defects. On the other hand, there is some risk of corrosion because condensed water penetration between glass sheets. Besides, areas so protected are easily visible because of their different reflexion.

Likewise, it has been considered the possibility of fixing the original glass to a protective glass sheet by a plastic intercalary as that used in security laminated glasses. However, the surface irregularities and the flat lack of stained glass windows, make impossible a good joint. To solve this inconvenient, the application of a polymeric filling mass to balance the glass case has been proposed. This mass has to be treated at $80^{\circ} \mathrm{C}$ to carry out its polymerization once the new glass layer is placed. Glass protection with a protective glass sheet suppose an important weight increase with the subsequent risk for its stability.

One of the most promising protective procedures consist of coating the glass surface with organically modified silicates (47). So, mixtures of tetraethoxysilane, diphenyldiclhorosilane and methylvinyldiclhorosilane have been employed. The main advantages of these type of hybrid materials is that alcoxysilanes have hydrophobe groups and that they provide a high number of Si-OH groups, ensuring a good glass adherence. On the other hand, they can be easily eliminated because they are very soluble in organic compounds.

\section{BIBLIOGRAFÍA}

(1) BRILL, R.H.: “A request for help in the conservation of early stained glass windows”. IX Intern. Congress on Glass, Paris 1971.

(2) VASSAS, C.D.: "Etude chimique, thermographique et physique de verres de vitraux du Moyen Age". IX Intern. Congress on Glass, Paris 1971.

(3) COX, G.A.; HEAVENS, O.S.; NEWTON, R.G.; POLLARD, A.M.: "A study of the weathering behavior of medieval glass from York Minster". J.Glass Stud. 21 (1979) 54-75.

(4) COX, G.A.; POLLARD, A.M.: "The multivariate analysis of data relating to the durability of medieval window glass". Rev. Archeom. 5 (198I) 119-128.

(5) MÜLLER, W.;FISCHER, A.; DRACHENBERG, E.: "Datierung von Scherbenfunden mittelalterlicher Glasmalerei". Silikattechn. 40 (1989) 292-295.

(6) MÜLLER, W.; TORGE, M.; ADAM, K.: "Ratio of $\mathrm{CaO} / \mathrm{K}_{2} \mathrm{O}>2$ as evidence of a special Rhenish type of medieval stained glass". Glastech. Ber. 67 (1994) 45-48. 
(7) TEOPHILUS: “De diversis artibus” (traducción inglesa). Johannes Murray, Londres, 1847.

(8) SCHREINER, M.: "Deterioration of stained medieval glass by atmospheric attack. Pt. 1: Scanning electron microscopic investigations of the weathering phenomena". Glastech. Ber. 61 (1988) 197-204.

(9) MÜLlER, W.: "Corrosion phenomena of medieval stained glasses”. Bol. Soc. Esp. Cerám. Vid. 31-C, Vol.1 (1992) $219-239$.

(10) GEILMANN, W.; JENEMANN, H.: "DerPhosphatgehalt alter Gläser und seineBedeutungfür dieGeschichteder Schmelztechnik". Glastech. Ber. 26 (1953) 259-263.

(11) PÉREZ Y JORBA, M.; DALLAS, J.P.; COLLONGUES, R.; BAHEZRE, C.; MARTIN, J.C.: "La corrosion atmosphérique d'un verre du Moyen-Age. Rôle du phosphore dans le mechanisme d'alteration". Riv.Stn. Sper. Vetro 14 (1984) 121-130.

(12) CHESNAU, M.G.: “Contribution à l'létude de la technique de vitraux du Moyen Age". Bull. Soc. d'Encouragement pour l'Industrie Nationale 132 (1933) 622.

(13) VASSAS, C.D.: "Etude colorimetrique de verres de vitraux du Moyen Age". IX. Intern. Congress on Glass, Paris 1971.

(14) BETTEMBOURG, J.M.: "Etude de verres bleus de vitraux. Analyse par spectrometrie d'absorption atomique". IX Intern. Congress on Glass, Paris 1971.

(15) KÜHNE, H.: "Beitrag zur Kenntnis mittelalterlicher Gläser". Silikattechn. 11 (1960) 260-262.

(16) GEILMANN, W.: “Beiträge zur Kenntnis alter Gläser. VII: Kobalt als Färbungsmittel”. Glastech. Ber. 35 (1962) 186-191.

(17) GEILMANN,. W.; BRÜCKBAUER, T.: “Beiträge zur Kenntnis alter Gläser. II: Der Mangangehalt alter Gläser”. Glastech. Ber. 27 (1954) 456-459.

(18) MÜLLER, W.; POUILLON, H.; BOCHINEK, G.; MEHNER, H.: "Extreme Dunkelung von Glasmalereien". Glastech. Ber. 59 (1986) 96-102.

(19) SELLNER, C.; OEL, H.J.; CAMARA,B.: "Untersuchung alter Gläser (Waldglas) auf Zusammenhang von Zusammensetzung, Farbe und Schmelzatmosphäre mit derElektronenmikroskopie und der Elektronenspinresonanz(ESR)": Glastech. Ber. 52(1979) 255-264.

(20) SCHREINER, M.: "Deterioration of stained medieval glass by atmospheric attack. Pt. 2. Secondary ion mass spectrometry analysis of the naturally weathered glass surfaces". Glastech. Ber. 61 (1988) 223-230.

(21) DURÁN, A.; FERNÁNDEZ NAVARRO, J.M".: "Coloring mechanism in copper ruby glasses". Glastech. Ber. 56 K. (1983) Band 1, 614-619.

(2) FERNÁNDEZ NAVARRO, J.M"a; LA IGLESIA; A: "Estudio de la coloración roja y amarilla de dos vidrios de la Catedral de Toledo". Bol. Soc. Esp. Cerám. Vid. 33 (1994) 6, 333-336.

(23) HREGELICH, S.; PROFILO, B.; VERITÁ, M.: "Studio della corrosione e colorazione dei vetri pottassici della vetrata della Chiesa dei Giovanni e Paolo a Venezia per mezzo della microsonda elettronica". Riv. Stn. Sper. Vetro 9 (1979) 53-61.

(24) SPITZER-ARON SON, M.: "Contribution à la connaissance des vitraaux du Moyen Age. Insuffisance de la diffusion pour expliquer la non concordance stricte entre la présence de cuivre et la coleur à l'interieur des verres des vitraux rouges". Verres Réfract. 30 (1976) 56-61.

(25) NEWTON, R.G.: "The durability of glass". A review. Glass Technol. 26 (1985) 21-38.

(20) GILLIES, K.J.S.; COX, A.: "Decay of medieval stained glass at York, Canterbury and Carlisle. Part 1. Composition of the glass and its weathering products". Glastech. Ber. 61 (1988) 75-84.

(27) FERNÁNDEZ NAVARRO, J.Ma: "El vidrio". Edit. Consejo Superior de Investigaciones Científicas, Madrid 1991.

(28) EL-SHAMY, T.M.; LEWINS, J.; DOUGLAS, R.W.: "The dependence on the pH of the decomposition of glasses by aqueous solutions". Glass Technol. 13 (1972) 81-87.

(29) FERNÁNDEZ NAVARRO; J.Ma: “Ataque de la superficie de un vidrio sódico-cálcico”. Sin publicar. 
(30) NAUER, G.; KNY, E.: “Korrosionsphänomene alter Gläser; ihre Untersuchung mittels Rasterelektronenmikroskopie". Beitr. elektronenmik. Direktabb. Oberfl. 10 (1977) 333-340.

(31) PÉREZ Y JORBA, M.; DALLAS, J.P.; COLLONGUES, R.; BAHEZRE, C.; MARTIN, J.C.: "Etude de l'altération des vitraux anciens par microscopie électronique à balayage et microsonde". Silicates Industr. 43 (1978) 89-99.

(32) DOUGLAS, R.W.; ISARD, M.A.: "The action of water and of sulphur dioxide on glass surfaces". J.Soc. Glass Technol. 33 (1949) 289-335.

(33) COLLONGUES, R.; PÉREZ Y JORBA, M.; TILLOCA, G.: "Nouveaux aspects du phénomène de corrosion des vitraux anciens des églises françaises". Verres Réfract. 30 (1976) 43-55

(34) GEILMAN, W.; BERTHOLD, H.J.; TÖLG, G.: "Beiträge zur Kenntnis alter Gläser. V: Die Verwitterungsprodukte auf Fensterscheiben". Glastech. Ber. 33 (1960) 213-219.

(35) NEWTON, R.G.; FUCHS, D.: "Chemical compositions and weathering of some medieval glasses from York Munster. Pt. 1". Glass Technol. 29 (1988) 43-48.

(36) FERRAZINI, J.C.: "L'influence de la corrosion sur la vitesse de décomposition des verres du Moyen Age". Verres Réfract. 30 (1976) 26-29.

(37) SCHREINER, M.: "Secondary ion mass spectrometer analysis of potash-lime-silica glasses leached in hydrochloric and sulfuric acids". J. Amer. Ceram. Soc. 72 (1989) 1713-1715.

(38) Pérez y Jorba, M; Tilloca, G.; Michel, D.; Dallas, J.P.: Quelques aspects du phénomène de corrosion des vitraux anciens des églises françaises. Verres et Réfract. 29 (1975) 53-63.

(39) GILLIES, K.J.S.; COX, A.: "Decay of medieval stained glass. Part. 2. Relationship between the composition of the glass, its durability and the weathering products". Glastech. Ber. 61 (1988) 101-107.

(40) PÉREZY JORBA, M.; DALLAS, J.P.;BAUER, C.: "Deterioration of stained glass by atmospheric corrosion and microorganisms". J. Mat. Sci. 15 (1980) 1640-1647.

(41) ILIFFE, C.J.; "Newton, R.G.: Using triangular diagrams to understand the behaviour of medieval glasses". Verres et Réfract. 30 (1976) 30-34.

(42) BetTeMBourg, J.M.: Composition et alteration des verres de vitraux anciens. Verres et Réfract. 30 (1976) 36-42.

(43) NEWTON, R.G.; PAUL, A.: "A new approach to predicting the durability of glasses from their chemical composition". Glass Technol. 21 (1980) 307-309.

(44) SCHREINER, M.; STINGEDER, G.; GRASSERBAUER, M.: "Quantitative characterization of surface layers on corroded medieval window glass with SIMS"; Fresenius Z. Anal. Chem. 319 (1984) 600-605.

(45) BETTEMBOURG, J.H.; BURCK, J.J.: "Traitement curatif des vitraux; le nettoyage". CV-News Letter 39/40 (1986) 7-14.

(40) JACOBI, R.: “Die Konservierung alter Glasmalereien des Kölner Doms”. Glastech. Ber. 30 (1957) 509-514.

(47) TÜNKER, G.; PATZELT, H.; SCHMIDT, H.: “Neue Wege zur Erhaltung historischer Glasfenster”. Glastech. Ber. 59(1986) 272278. 